GHANA JOURNAL OF DEPARTMENT OF HEALTH, PHYSICAL EDUCATION AND RECREATION, SPORTS AND DANCE (GJOHPERSD)

Volume 7 \& 8, Year 2014 \& 2015

A JOURNAL OF THE DEPARTMENT OF HEALTH, PHYSICAL EDUCATION AND RECREATION (HPER)

UNIVERSITY OF CAPE COAST

GHANA, WEST AFRICA 


\title{
PEDAGOGICAL CONTENT KNOWLEDGE OF PRE- SERVICE TEACHERS' IN PHYSICAL EDUCATION: A CASE STUDY OF KOMENDA COLLEGE OF EDUCATION
}

1Ogum, N. Prosper*, 2Ocansey, T. Reginald, 3Mintah, K. Joseph, \& 4Ogum, A. Mary

1\&3Department of Health, Physical Education and Recreation, University of Cape Coast, Ghana 2Department of Physical Education and Sports Studies, University

of Ghana, Legon, Accra, Ghana

4University Practice Senior High School, Cape Coast, Ghana E-mail: pogum@ucc.edu.gh; Tel.+233-243-514-178

\begin{abstract}
The study assessed the pedagogical content knowledge of preservice teachers in Physical Education at the Colleges of Education in Ghana. The descriptive survey design was employed to conduct the study. One hundred and eighty (180) final year students were randomly selected for the study. A questionnaire was used to collect the data for the study. Data were analyzed using frequencies and percentages. The results indicated that pre-service teachers at the colleges received sufficient instructions in physical education about the subject matter and general pedagogical practices to enable them teach the content of instruction effectively to enhance positive learning outcomes in their students. Also, preservice teachers acquired adequate knowledge about their learners and their characteristics to make them effective teachers in Physical Education. Thus, the teacher education division must keep to, monitor and supervise the present syllabus being used by


Pedagogical Contents Knowledge of Pre-Service

Teachers' in Physical Education

the Colleges of Education since the pre-service teachers in this study have proved that they received sufficient instructions to make them effective teachers in Physical Education.

Key words: Pedagogical content knowledge, characteristics of the context of learning, colleges of education, pre-service teachers

56 A Journal of the Department of Health, Physical Education and Recreation 


\section{Introduction}

The beginning of formal education in Ghana can be traced to the coming of the Europeans. The introduction of Castle Schools and Mission Schools gave Ghana the needed foundation for the current educational system. Education at the time of the Castle Schools focused mainly on the 3Rs (Reading, Writing and Arithmetic). Physical education as a school subject at that time received no attention. It was during the time of Sir Gordon Guggisberg, the then Governor of the Gold Coast, that the sixteen principles of education were introduced. The 9th principle states that every school should have a field of play for physical education, recreation and sports. This principle also emphasized that; every child of school going age should be admitted and allowed to play sports (McWilliams, \& Kwamena-Poh, 1978). The introduction of the Accelerated Development Plan for Education in 1951 also made the teaching of Physical Education a policy in the country (McWilliams, \& Kwamena-Poh, 1978).

Physical Education concerns the teaching of motor skills and movement patterns needed to perform a variety of physical activities planned and directed by schools to achieve and maintain a healthy enhancing level of physical fitness (Ghana Physical Education and Sports Thinktank [GPESTt], 2009). Thus, by the time a student graduates from school, the student should be able to participate regularly in physical activity. Put differently, the student should be able to demonstrate, practice and persist in physically active lifestyle. This is because physical education guided by learning standards, provides opportunities for students to choose to be physically active and to value physical activity. Fostering a physically active lifestyle in students must be recognized as an ultimate goal of physical education.

The teaching of Physical Education enables the individual to develop interest and motivation to use motor skills and movement patterns in ways to enhance a physically active lifestyle. This implies that pre-service teachers of Physical Education need to possess proper and adequate pedagogical content knowledge (PCK) to be able to teach the subject matter knowledge effectively. Pedagogical content knowledge has therefore been embraced by 
Pedagogical Contents Knowledge of Pre-Service

Teachers' in Physical Education

many of the educational reforms in the world as a way of describing the knowledge possessed by expert teachers (Shulman, 1986). It is that form of knowledge that makes teachers to be teachers rather than subject area experts (Shulman, 1986). It also refers to teachers' knowledge about the basic teaching or learning matters such as learning theories, teaching approaches, curriculum designs, evaluation techniques, and relevant managerial issues (Albalawi, \& Badawi, 2008).

Furthermore, PCK has also been viewed as a set of special attributes that help teachers to transfer the knowledge of content to others (Geddis, 1993). Additionally, PCK is a type of knowledge that is unique to teachers, and in fact is what teaching is about. It concerns the manner in which teachers relate their pedagogical knowledge (what they know about teaching) to their subject matter knowledge (what they know about what they teach), in the school context, for the teaching of specific students. It is the integration or the synthesis of teachers' pedagogical knowledge and their subject matter knowledge that comprises PCK.

Over the past years, the major focus in pedagogical research has been in the area of teacher effectiveness (Geddis, 1993). Many of the studies have dealt with the improvement of teaching skills and/or the effect of teacher or student behaviours on student achievement. However, basic school children need quality and effective tuition in Physical Education in order to nurture adherence habits for physical activity. In fact, Colleges of Education can contribute immensely to the physical activity needs of children if basic school pre-service teachers are given the chance to acquire knowledge, skills, and attitudes needed for quality basic school Physical Education teaching (Ghana Physical Education, \& Sports Thinktank [GPESTt], 2009).

Pre-service teachers from Colleges of Education represent a frontline in the development of skills and attitudes that enable children and adolescents to engage in regular physical activity. The education of the youth to regularly participate in physical activity in the future starts with teachers in the lower basic school level. Colleges of Education are strategically positioned to provide the foundation of knowledge, skills, and learning experiences that pre- 
service teachers need to promote active living in learners in basic schools (GPESTt, 2009).

Studies conducted so far on teacher effectiveness have revealed that if pre-service teachers receive proper and adequate curricula offerings in teacher preparation in Physical Education, they will be able to provide fundamentally and developmentally appropriate experiences for students to learn in order to develop adherence to physical activity (Ball, \& McDiarmid, 1990). Contrarily, a report by GPESTt (2009) has revealed that Physical Education is woefully taught at the basic school level in the country. According to the GPESTt, it is difficult to point at any worthy subject matter knowledge and pedagogical knowledge that teachers acquire at training which will enable them teach the subject effectively so that they can in turn impact the lives of learners in basic schools in a positive way. What then is going on at the colleges of education with regards to curricula offerings in teacher preparation in physical education? It is based upon the afore- mentioned that this study sought to provide in-depth appraisal of teacher knowledge on i) subject matter, ii) pedagogy, and the iii) characteristics of context of learning in Physical Education at the Colleges of Education in Ghana.

\section{Method}

The descriptive survey design was used to assess pre-service teachers' PCK in Physical Education at the Colleges of Education in Ghana. The population for the study comprised all the 266 final year students of Komenda College of Education who were on the field having their teaching practice. The reason for selecting the final year students was that they were out of campus doing the "Out" component of their In-In-Out programme and could therefore relate theoretical knowledge to practical knowledge. One hundred and eighty final year students were randomly selected for the study. They were assured of anonymity and confidentiality of their responses. A questionnaire developed by the researchers was used to elicit responses from the respondents. This consisted of 15 closed ended items on a four point Likert scale of strongly agree (SA), agree (A), disagree (D) and strongly disagree (SD) which yielded an alpha reliability coefficient of .67. Frequencies and 
Pedagogical Contents Knowledge of Pre-Service

Teachers' in Physical Education

percentages were used to report on the current status of pre-service teachers' pedagogical content knowledge in physical education at the Colleges of Education in Ghana.

\section{Results}

Results from table 1 indicate that 97\% (174) of the participants either agreed or strongly agreed that they received adequate subject matter at training while $83 \%$ (150) believed their knowledge was influenced by field experiences. Similarly, 85\% (153) of the participants either agreed or strongly agreed that their confidence in teaching physical education was boosted by the amount of knowledge they received at training while $73 \%$ (132) agreed or strongly agreed that their teaching style was influenced by the way they have learnt the content at training. Again, 64\% (116) of the participants either agreed or strongly agreed that they did not use trial and error strategies in teaching the content of instruction to students since they knew the content and what strategies to use to teach every aspect of the content.

\section{Table 1: Scope of Subject Matter Knowledge of Pre-Service} Teachers in Physical Education

\begin{tabular}{|c|c|c|c|c|}
\hline Statement & $\begin{array}{l}\text { SA } \\
\mathrm{f} \\
\%\end{array}$ & $\begin{array}{c}\mathrm{A} \\
\mathrm{f} \\
\%\end{array}$ & $\begin{array}{l}\mathrm{D} \\
\mathrm{f} \\
\%\end{array}$ & $\begin{array}{l}\text { SD } \\
\mathrm{f} \%\end{array}$ \\
\hline $\begin{array}{l}\text { 1. I received at training } \\
\text { adequate subject matter }\end{array}$ & & & & \\
\hline knowledge and this affects my & 88 & 86 & 1 & \\
\hline processes of instruction & 48.8 & 47.8 & 0.6 & 52.8 \\
\hline 2. My knowledge seems to be & 56 & 94 & 20 & 10 \\
\hline influenced by field experiences & 31.1 & 52.2 & 11.1 & 5.6 \\
\hline $\begin{array}{l}\text { 3. The amount of knowledge I } \\
\text { received during training } \\
\text { boosted my confidence in }\end{array}$ & & & & \\
\hline teaching practical physical & 80 & 73 & 21 & \\
\hline education & 44.4 & 40.6 & 11.7 & 63.3 \\
\hline 4. The way I teach the content & 24 & 40 & 86 & 30 \\
\hline of physical education is not & 13.1 & 22.2 & 47.8 & 16.7 \\
\hline
\end{tabular}


influenced by the way I have

learnt it

5. I use trial and error strategies

when

delivering the content to

19

10.6

$34 \quad 75$

52

students

$18.9 \quad 41.7 \quad 28.9$

Table 2 also shows that $91 \%$ (164) of the participants either agreed or strongly agreed that they learnt at training how to use demonstrations, simulations and questioning strategies to explain concepts to learners while $62 \%$ (112) either agreed or strongly agreed that they acquired at training a wide range of teaching and learning styles to enable them create a healthy learning environment when teaching. Also, 89\% (160) either agreed or strongly agreed that they learnt their classroom management practices through field experiences, field observations and students' teaching while $73 \%$ (132) either agreed or strongly agreed that they were aware of individual student skill differences when teaching motor content. Furthermore, 64\% (116) of the participants either agreed or strongly agreed that they used peer coaching in their teaching because they are aware of it.

Table 2: Scope of Pedagogy Knowledge of Pre-Service Teachers in Physical Education

\begin{tabular}{|c|c|}
\hline$S A$ & $\mathrm{~A}$ \\
\hline
\end{tabular}

1. I learnt how to use

demonstrations, simulation

and questioning strategies to

explain a concept to learners

at training

$\begin{array}{llllllll}79 & 43.3 & 85 & 47.2 & 11 & 6.1 & 5 & 2.8\end{array}$

2. I did not acquire at

training how to display a

wide range of teaching

and learning styles that

lead to creating a healthy

A Journal of the Department of Health, Physical Education and Recreation 
Pedagogical Contents Knowledge of Pre-Service

Teachers' in Physical Education learning environment

$\begin{array}{lllllll}28 & 15.6 & 40 & 22.2 & 74 & 41.138 & 21.1\end{array}$

3. I learnt my classroom managementpractices through experiences, field observations and students teaching $\begin{array}{llllllll}79 & 43.8 & 81 & 45.0 & 10 & 5.6 & 10 & 5.6\end{array}$

4. I am not aware of individual student skill differences when teaching motor content

5. I do not use peer coaching in my teaching because I am not aware of peer coaching $\begin{array}{lllllllll}\text { functions and techniques } & 28 & 15.6 & 36 & 20 & 87 & 48 & 29 & 16.1\end{array}$

Table 3 shows that $88 \%$ (159) of the participants either agreed or strongly agreed that good teaching is highly related to one's content knowledge and the ability to convey that knowledge to others while $60 \%$ (92) either agreed or strongly agreed that they have a limited knowledge of their students' culture and religion. Also, 55\% (99) of the participants either agreed or strongly agreed that their perception played a pivotal role in the way they acquired knowledge during training while 65\% (117) either agreed or strongly agreed that their thoughts, interpretation and use of information is influenced by their prior experiences. Again, 71\% (128) of the participants either agreed or strongly agreed that their understanding and interpretation of students' emotions affect their selection of content and methods of teaching to facilitate students learning. 
Table 3: Characteristics of the Context of Learning in Physical Education

SA
f $\%$

1. I believe that good teaching is highly related to one's content knowledge and ability to convey that knowledge to others $\quad \begin{array}{llllllll}100 & 55.6 & 59 & 32.7 & 10 & 6.1 & 11 & 5.6\end{array}$

2. I have a limited knowledge of my students' culture and religion

$\begin{array}{llllllll}15 & 8.3 & 77 & 42.9 & 62 & 34.4 & 26 & 14.4\end{array}$

3. My perceptions did not play a pivotal role in the way I acquired knowledge during training $\begin{array}{llllllll}23 & 12.2 & 59 & 32.8 & 78 & 43.3 & 21 & 11.7\end{array}$

4. The way I think, interpret and make use of new information is not influenced by $\begin{array}{lllllllll}\text { my prior experiences } & 3 & 1.7 & 60 & 33.3 & 90 & 50 & 27 & 15\end{array}$

5. My understanding and interpretation of students' emotion does not affect my selection of content and methods of teaching to facilitate students learning $\begin{array}{llllllll}11 & 6.1 & 41 & 22.8 & 48 & 26.7 & 80 & 44.4\end{array}$

\section{Discussion}

The findings revealed that pre-service received at training adequate knowledge about the subject matter, general pedagogical knowledge and knowledge about learners and their characteristics to make them effective teachers of physical education. This finding is supported by Grossman et al. (2005) and Grossman (1990) who 
Pedagogical Contents Knowledge of Pre-Service

Teachers' in Physical Education

stressed that teachers' subject matter knowledge is key to effective teaching since subject matter knowledge influences what preservice teachers teach and the methods of instruction used during teaching. Similarly, McDiarmid, Ball, and Anderson (1989) observed that teachers capacity to pose questions, select tasks, evaluate their pupils' understanding and make curricular choices all depend on the amount of subject matter they have received at training and how they themselves understand the subject matter. This implies that teachers need much deeper and more critical understanding of the subject matter to be able to develop, select and use appropriate representation to ensure effective teaching. The findings also suggests that the pedagogy component of the physical education teacher education programme in Ghana provide opportunities for pre-service teachers to acquire at training specific knowledge of how to manage, assess, and instructionally facilitate student learning through text. Additionally, the findings show that pre-service teachers acquire at training knowledge about teaching strategies, information to plan, and when to use a variety of teaching styles for the understanding of concepts and lesson content to facilitate student learning. Furthermore, the findings suggest that the acquisition of general pedagogical knowledge during methods course enabled the pre-service teachers to prepare adequately as well as organize and manage the learning environment to enhance effective use of instructional time. Rovegno et al. (2003) revealed that when pre-service teachers are aware of a wide variety of teaching or instructional strategies for the teaching of a particular content of instruction, they are able to explain concepts to learners to enhance positive learning outcomes. Kinchin and O'Sullivan (2003) corroborated Rovegno et al. when they indicated that when pre-service teachers' are aware of a wide variety of teaching or instructional strategies, they are able to design their instructional tasks, group decision making and problem solving to give students a sense of ownership and control of their learning experience to enhance student engagement and success during the learning process.

The findings of this study again have shown that the pre-service teachers have knowledge of their learners and their characteristics 64

A Journal of the Department of Health, Physical Education and Recreation 
to ensure positive learning outcomes in their students. Simply stated, the pre-service teachers acquired at training knowledge about students emotions to help them design instructional task and create a healthy learning environment to enhance effective use of instructional time. Furthermore, pre-service teachers are aware of the perceptions and experiences that students are likely to bring into the classroom during teaching. As a result, they are able to reconcile students previously held information with new knowledge to aid students understanding of the content.

Hargreaves (1998b, 1998c) observed that the emotional understanding teachers share with their students appears to influence teaching and learning. McCaughtry (2004) found that teachers' understanding and interpretation of student emotion affect their selection, order, and formulation of curriculum units as well as pedagogical approaches and interactions during instruction in order to facilitate students learning. McCaughtry and Rovegno (2003) also pointed that students' emotional reactions to a teacher's instruction can provide the teacher with critical information to evaluate its success and future instruction. Similarly, Hargreaves (1998b, 1998c) and McCaughtry (2004b, 2005) noted that teachers' interpretations of students' emotional dispositions and personalities influence how they provide feedback, assign leadership positions, plan management strategies, pedagogical approaches, and curricular structures. Pajares (1992) reported that pre-service teachers' perceptions are key to the way they acquire knowledge and interpret course material to support their own perceptions about teaching during pedagogical training. Conclusions

Pre-service teachers at the Colleges of Education in Ghana received at training sufficient instructions in Physical Education about the subject matter, general pedagogical practices and information about their learners and their characteristics to enable them teach the content of instruction effectively to enhance positive learning outcomes in their students. Also, pre-service teachers acquired at training adequate knowledge about their learners and their characteristics to make them effective teachers in Physical Education. These imply that content of the curriculum is 
Pedagogical Contents Knowledge of Pre-Service

Teachers' in Physical Education

well tailored to meet the teaching demands of prospective teachers. Thus, the education division must keep to, monitor and supervise the present syllabus being used by the Colleges of Education since the pre-service teachers in this study have proved that they received sufficient instructions to make them effective teachers in Physical Education.

\section{References}

Albalawi, A., \& Badawi, M. (2008). Teachers' perception of elearning at the University of Tabuk. In G. Richards (Ed.), Proceedings of world conference on e-learning in corporate, government, healthcare, and higher education 2008 (pp. 2434-2448). Chesapeake, VA: AACE.

Ball, D., \& MacDiarmid, G. (1990). The subject matter preparation of teachers. In W.R. Housron (Ed.), Handbook of research on teacher education (pp. 437-449), New York: Macmillan.

Fraenkel, J. R., \& Wallen, N. E. (2000). How to design and evaluate research in education. (4th ed.). Boston: McGraw- Hill Inc.

Ghana Physical Education and Sports think Tank. (2009, July 29). Are there physical education teachers at the elementary school level? Ghanaian Times (No. 13442), p. 22.

Grossman, P. L. (1990). The making of a teacher: Teacher knowledge and teacher education. New York: Teacher College Press.

Grossman, P., Schoenfeld, A., \& Lee, C. (2005). Teaching subject matter. In L. Darling-Hammond \& J. Bransford (Eds.), Preparing teachers for changing world (pp. 201-231). San Francisco: Jossey-Bass.

Hargreaves, A. (1998b). The emotional practice of teaching. Teaching and Teacher Education, 14, 835-854.

Hargreaves, A. (1998c). The emotions of teaching and educational change. In A. Hargreaves (Ed.), International handbook of educational change, (pp. 558-575). London: Kluwer Academic Publishers. 
Kinchin, G., \& O’ Sullivan, M. (2003). Incidences of student support for and resistance to a curricular innovation in high school physical education. Journal of Teaching in Physical Education, 22, 245-257.

McCaughtry, N. (2004). The emotional dimensions of a teacher's pedagogical content knowledge: Influences on content, curriculum, and pedagogy. Journal of Teaching in Physical Education, 23, 30-47.

McCaughtry, N. (2004b). The emotional dimensions of a teacher's pedagogical content knowledge: Influences on content, curriculum and pedagogy. Journal of Teaching in Physical Education, 23, 30-47.

McCaughtry, N., \& Rovegno, I. (2003). The development of pedagogical content knowledge: Moving from blaming students to predicting skilfulness, recognizing motor development, and understanding emotion. Journal of Teaching in Physical Education, 22, 355-368.

McWilliam, H. O. A., \& Kwame-Poh, M. A. (1978). The Development of education in Ghana. Hong Kong: Commonwealth Printing Press Ltd.

Pajares, M. F. (1992). Teachers' beliefs and educational research: Cleaning up a messy construct. Review of Educational Research, 62 (3), 307-332.

Rovegno, I., Chen, W., \& Todorovich, J. (2003). Accomplished teachers' pedagogical content knowledge of teaching dribbling to third grade children. Journal of Teaching in Physical Education, 22, 426-449.

Shulman, L. S. (1987). Knowledge and teaching: Foundations of the new reform. Harvard Educational Review, 57, 122. 